\title{
1 COVID-19 Antibody in Thai Community Hospitals
}

2 Tanawin Nopsopon, M.D.

3 Lecturer, Department of Preventive and Social Medicine, Faculty of Medicine, Chulalongkorn University, Bangkok,

4 Thailand

5 tnopsopon@gmail.com

7 Krit Pongpirul, M.D., M.P.H., Ph.D. (Corresponding Author)

8 Assistant Professor, Department of Preventive and Social Medicine, Faculty of Medicine, Chulalongkorn

9 University, Bangkok,

10 Thailand; Department of International Health, Johns Hopkins Bloomberg School of Public Health, Baltimore,

11 MD, USA; Bumrungrad International Hospital, Bangkok, Thailand

12 doctorkrit@gmail.com

13

14 Korn Chotirosniramit

15 Medical Student, Faculty of Medicine, Chulalongkorn University, Bangkok, Thailand

16 korn.chotiros@gmail.com

17

18 Narin Hiransuthikul, M.D., Ph.D.

19 Professor, Department of Preventive and Social Medicine, Faculty of Medicine, Chulalongkorn University,

20 Bangkok, Thailand

21 narin.h@chula.ac.th

22

23 Words: 2,381 words (Text), 217 words (Abstract), 5 tables, 1 figure 


\section{Abstract}

25 Background: COVID-19 seroprevalence data has been scarce, especially in less developed countries with a 26 relatively low infection rate.

27 Methods: A locally developed rapid IgM/IgG test kit was used for screening hospital staff and patients who

28 required procedural treatment or surgery in 52 hospitals in Thailand from April 8 to June 26, 2020. A total of 857

29 participants were tested-675 were hospital staff and 182 were pre-procedural patients. (Thai Clinical Trials

30 Registry: TCTR20200426002)

\section{Results}

32 Overall, $5.5 \%$ of the participants (47 of 857) had positive immunoglobulin M (IgM), $0.2 \%$ (2 of 857) had positive

33 immunoglobulin $\mathrm{G}(\mathrm{IgG})$ and $\operatorname{IgM}$. Hospitals located in the Central part of Thailand had the highest IgM

34 seroprevalence (11.9\%). Preprocedural patients had a higher rate of positive IgM than the hospital staff (12.1\% vs.

$353.7 \%$ ). Participants with present upper respiratory tract symptoms had a higher rate of positive IgM than those

36 without (9.6\% vs. $4.5 \%)$. Three quarters $(80.5 \%, 690$ of 857$)$ of the participants were asymptomatic, of which, 31

37 had positive IgM (4.5\%) which consisted of 20 of 566 healthcare workers (3.5\%) and 11 of 124 preprocedural

38 patients $(8.9 \%)$.

\section{Conclusions}

40 COVID-19 antibody test could detect a substantial number of potential silent spreaders in Thai community hospitals.

41 Antibody testing should be encouraged for mass screening, especially in asymptomatic individuals.

42

43 MeSH Keywords: COVID-19, severe acute respiratory syndrome coronavirus 2, Seroepidemiologic Studies,

$44 \quad$ Hospitals, Thailand 
medRxiv preprint doi: https://doi.org/10.1101/2020.06.24.20139188; this version posted July 4, 2020. The copyright holder for this preprint (which was not certified by peer review) is the author/funder, who has granted medRxiv a license to display the preprint in perpetuity. It is made available under a CC-BY-NC-ND 4.0 International license .

45

46

47

\section{Age-adjusted seroprevalence}

70

71

\section{Introduction}

\section{Methods}

Polymerase chain reaction (PCR) was introduced as a diagnostic test of choice for coronavirus disease 2019 (COVID-19) infection. However, it might not be readily available or affordable in many facilities and could pose an unnecessary risk to the healthcare providers during the specimen collection. Besides, a recent study raised a concern of false-negative results from the PCR test for severe acute respiratory syndrome coronavirus 2 (SARS-CoV-2) in patients with high pretest probability and encouraged the development of a highly sensitive test [1]. In Thailand, the PCR test was offered in suspected individuals with strict criteria during the initial phase of the COVID-19 pandemic. As a more feasible, cheaper, and safer alternative to the PCR, the antibody test is not only useful for an epidemiological investigation [2] but could also be used for mass screening of potential silent spreadersasymptomatic COVID-19 individuals.

Hospital is one of the best venues for getting and spreading pathogens. There are two types of people in the hospital who potentially are silent spreaders and need antibody testing: (1) healthcare workers who have a relatively higher risk of infection than laypersons, and (2) asymptomatic patients who need procedural treatment or operation but do not meet the criteria for PCR testing.

From April 8 to June 26, 2020, hospital staff and patients who needed procedural treatment or operation but did not meet the national PCR testing criteria in 244 hospitals (215 community hospitals and 29 general hospitals) from all regions of Thailand were offered antibody testing. Of 215 community hospitals, data from 52 hospitals (24.2\%) in 35 provinces were readily available for the analysis performed on June 29, 2020. Patients with PCR confirmed COVID-19 infection were quarantined and excluded. Baiya Rapid COVID-19 IgG/IgM test kit (Baiya Phytopharm, Thailand) which reports the presence of immunoglobulin M (IgM) and immunoglobulin G (IgG) qualitatively, was used in this study free of charge. The internal validation of the test kit using the serum of 51 PCR confirmed COVID-19 cases and 150 controls showed sensitivity 94.1\% (48 of 51) and specificity 98.0\% (147 of 150) for IgM or IgG antibody. Participants with positive IgM were encouraged to have a PCR test if available.

PCR confirmed COVID-19 cases were obtained from the Thailand government report on June 30, 2020.

Seroprevalence data were presented as unadjusted seroprevalence and compared with direct age-adjusted 
medRxiv preprint doi: https://doi.org/10.1101/2020.06.24.20139188; this version posted July 4, 2020. The copyright holder for this preprint

(which was not certified by peer review) is the author/funder, who has granted medRxiv a license to display the preprint in perpetuity.

It is made available under a CC-BY-NC-ND 4.0 International license .

72 seroprevalence using combined participating population, Thailand population, and world population provided by

73 world health organization (WHO) for 2000-2025 population.

\section{$74 \quad$ Statistical analysis}

75 Categorical data were presented with counts and percentages while continuous data were provided with median and

76 interquartile range. The $95 \%$ confidence interval (CI) of the seroprevalence was calculated by Wilson's method

77 using binomial probabilities. Correlation between seroprevalence and PCR confirmed COVID-19 prevalence was

78 tested using Spearman's correlation. Missing data were excluded. A two-tailed $p<0.05$ was considered statistically

79 significant. All data were analyzed using Stata 16.1 (College Station, TX).

\section{Ethics Committee Approval}

81 This study was approved by the Institutional Review Board of Chulalongkorn University (IRB No.236/63) and 18

82 general hospitals. Given no ethics committees were available in the participating community hospitals, participation

83 in this study was approved by the hospital directors or representatives. All participants provided written informed

84 consent. (Thai Clinical Trials Registry: TCTR20200426002)

\section{Results}

86 Overall, 52 community hospitals from $46.1 \%$ of provinces in Thailand ( 35 of 76 ) which consisted of $58.2 \%$ of

87 national population $(35,416,545$ of $60,892,671)$ participated in this study. Participation rates varied across regions-

88 Northeastern (55\%), Central (50.0\%), Southern (42.9\%), Northern (33.3\%), and Eastern (28.6\%) [Table 1].

89 
medRxiv preprint doi: https://doi.org/10.1101/2020.06.24.20139188; this version posted July 4, 2020. The copyright holder for this preprint (which was not certified by peer review) is the author/funder, who has granted medRxiv a license to display the preprint in perpetuity.

It is made available under a CC-BY-NC-ND 4.0 International license.

91 Table 1. Geographical Distribution of 52 Participating Community Hospitals

\begin{tabular}{lrrrr}
\hline & $\begin{array}{c}\text { Participating } \\
\text { Provinces }\end{array}$ & $\begin{array}{c}\text { Total } \\
\text { Provinces }\end{array}$ & $\begin{array}{c}\text { Population of } \\
\text { Participating Provinces }\end{array}$ & $\begin{array}{c}\text { Population of } \\
\text { All Provinces }\end{array}$ \\
\hline Thailand* & $35(46.1 \%)$ & 76 & $35,416,545(58.2 \%)$ & $60,892,671$ \\
Northern & $3(33.3 \%)$ & 9 & $2,505,118(39.4 \%)$ & $6,350,499$ \\
Northeastern & $11(55.0 \%)$ & 20 & $15,064,919(68.4 \%)$ & $22,014,248$ \\
Central* & $13(50.0 \%)$ & 26 & $10,053,397(55.3 \%)$ & $18,192,361$ \\
Southern & $6(42.9 \%)$ & 14 & $5,697,112(60.0 \%)$ & $9,493,757$ \\
Eastern & $2(28.6 \%)$ & 7 & $2,095,999(43.3 \%)$ & $4,841,806$ \\
\hline
\end{tabular}

92 * Not include Bangkok which has no community hospital.

93 Data were presented in counts and percentages.

94

From 52 community hospitals, 857 participants which consisted of 675 hospital staff and 182 pre-

96 procedural patients were included in the study. Their median age was 37 years (interquartile range 27-45), 74.7\%

97 were female, $98.8 \%$ were Thai, and $80.5 \%$ were asymptomatic. The most common symptoms were cough $(9.7 \%)$,

98 rhinitis (7.5\%), sore throat (6.4\%), fever (5.7\%), and dyspnea (3.5\%). History of travel to the high-risk area was

$996.0 \%$, history of close contact to the confirmed COVID-19 case was $15.4 \%$, and $14.5 \%$ had PCR negative. Forty-

100 seven participants (5.5\%, 95\% CI 4.1-7.2) had IgM antibody against SARS-CoV-2 whereas the IgG antibody was

101 found in two participants $(0.2 \%, 95 \%$ CI $0.1-0.8)$. Participants from the Central region of Thailand had the highest

102 IgM seroprevalence (11.9\%, 95\% CI 8.4-16.5), while the Northern region had the lowest seroprevalence (1.6\%,

$10395 \%$ CI 0.3-8.7) [Fig 1]. 


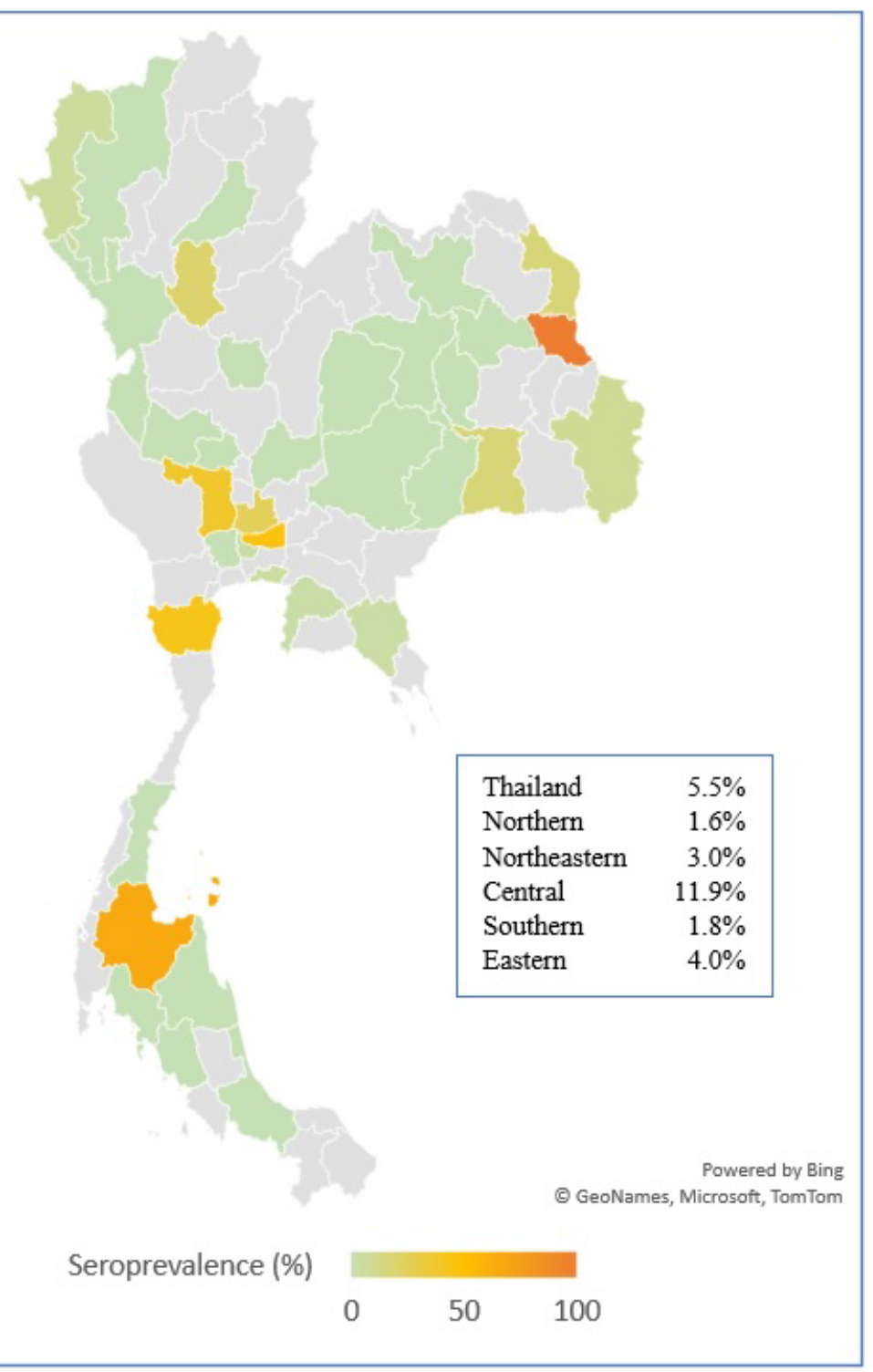

Fig 1. Unadjusted IgM Seroprevalence in Community Hospitals across Geographical Regions of Thailand.

108 with unadjusted IgM seroprevalence. However, age-adjusted seroprevalence using Thailand population showed 109 increasing seropositive rate in Thailand from 5.5\% to 6.3\%, Central region from $11.9 \%$ to $15.3 \%$, and Northern region from $1.6 \%$ to $1.8 \%$, while decreasing seroprevalence in Northeastern region from $3.0 \%$ to $1.6 \%$, Eastern

111 region from $4.0 \%$ to $2.8 \%$, and Southern region from $1.8 \%$ to $1.5 \%$. Adjusted with the world standard population 
medRxiv preprint doi: https://doi.org/10.1101/2020.06.24.20139188; this version posted July 4, 2020. The copyright holder for this preprint (which was not certified by peer review) is the author/funder, who has granted medRxiv a license to display the preprint in perpetuity.

It is made available under a CC-BY-NC-ND 4.0 International license .

112 from the World Health Organization (WHO 2000-2025) showed decreasing trends of seroprevalence both overall

113 and in most regions [Table 2].

114 Table 2. Unadjusted and age-adjusted immunoglobulin M seroprevalence in community hospitals across

115 geographical regions of Thailand

\begin{tabular}{lrrrr}
\hline & $\begin{array}{l}\text { Unadjusted IgM } \\
\text { Seroprevalence }\end{array}$ & $\begin{array}{c}\text { Age-adjusted IgM } \\
\text { Seroprevalence with Combined } \\
\text { Participating Population }\end{array}$ & $\begin{array}{c}\text { Age-adjusted IgM } \\
\text { Seroprevalence with } \\
\text { Thailand Population }\end{array}$ & $\begin{array}{c}\text { Age-adjusted IgM } \\
\text { Seroprevalence with World } \\
\text { Standard Population }\end{array}$ \\
\hline Thailand* & $5.5 \%$ & NA & $6.3 \%$ & $5.1 \%$ \\
Northern & $1.6 \%$ & $2.2 \%$ & $1.8 \%$ & $2.1 \%$ \\
Northeastern & $3.0 \%$ & $3.0 \%$ & $1.6 \%$ & $1.5 \%$ \\
Central & $11.9 \%$ & $11.9 \%$ & $15.3 \%$ & $12.2 \%$ \\
Southern & $1.8 \%$ & $2.4 \%$ & $1.5 \%$ & $1.2 \%$ \\
Eastern & $4.0 \%$ & $3.9 \%$ & $2.8 \%$ & $2.6 \%$ \\
\hline
\end{tabular}

* Not include Bangkok which has no community hospital

IgM, immunoglobulin M; NA, not available; WHO, World Health Organization.

Pre-procedural patients had an unexpectedly higher proportion of positive IgM than the hospital staff

(12.1\% vs. $3.7 \%)$, especially patients in the Central region of Thailand $(27.9 \%, 95 \%$ CI $18.2-40.2)$ while patients in the Northern and Southern regions showed zero seroprevalences. Also, hospital staff in the Central region had the highest seroprevalence $(6.6 \%, 95 \%$ CI $3.8-11.1)$ while those in the Northern region had the lowest $(1.7 \%, 95 \%$ CI

123 0.3-9.0). Overall, the seropositive prevalence was not different between males and females (5.8\% vs. 5.5\%).

124 Paradoxically, the seroprevalences were higher in participants without a history of travel to the high-risk area (5.6\%

125 vs. $3.9 \%$ ) and those without a history of close contact to confirmed COVID-19 case (5.7\% vs. $4.5 \%)$ than their

126 counterparts. The same paradox also applied to pre-procedural patients. Patients without travel history were likely to

127 have an antibody for SARS-CoV-2 (13.9\% vs. 3.2\%) and patients without close contact to the case also had more

128 chance to develop an antibody (12.3\% vs. 9.1\%). However, healthcare workers with travel history had slightly more

129 chance to develop IgM (5.0\% vs. 3.7\%) and with close contact history (4.1\% vs. 3.6\%). In general, participants with

130 upper respiratory tract symptoms had a higher chance of being seropositive (9.6\% vs. $4.5 \%)$, of which dyspnea had

131 the highest (30.0\%, 95\% CI 16.7-47.9). Likewise, pre-procedural patient with dyspnea had the most IgM positive

132 (29.6\%, 95\% CI 15.9-48.5) and healthcare worker with dyspnea (33.3\%, 95\% CI 6.1-79.2). Of 690 participants 
medRxiv preprint doi: https://doi.org/10.1101/2020.06.24.20139188; this version posted July 4, 2020. The copyright holder for this preprint (which was not certified by peer review) is the author/funder, who has granted medRxiv a license to display the preprint in perpetuity.

It is made available under a CC-BY-NC-ND 4.0 International license .

without present upper respiratory tract symptom, 31 had IgM positive for COVID-19 (4.5\%, 95\% CI 3.2-6.3) which consisted of 20 of 566 healthcare workers $(3.5 \%, 95 \%$ CI $2.3-5.4)$ and 11 of 124 patients $(8.9 \%, 95 \%$ CI $5.0-15.2)$.

Table 3. Demographic Characteristics and Seroprevalence in different groups

\begin{tabular}{|c|c|c|c|c|c|c|c|}
\hline & \multicolumn{2}{|c|}{ All Participants } & \multicolumn{3}{|c|}{ Hospital Staff } & \multicolumn{2}{|c|}{ Pre-procedural Patients } \\
\hline & $\mathbf{n}$ & IgM+ & $\mathbf{n}$ & & IgM+ & $\mathbf{n}$ & IgM+ \\
\hline Total & 857 & $47(5.5 \%)$ & 675 & & $25(3.7 \%)$ & 182 & $22(12.1 \%)$ \\
\hline $\begin{array}{l}\text { Median age, years } \\
\text { (25th-75th percentile) }\end{array}$ & \multicolumn{2}{|l|}{$37(27-45)$} & \multicolumn{3}{|c|}{$36.5(28-45)$} & \multicolumn{2}{|l|}{$37(25-53)$} \\
\hline Male, n (\%) & $207(24.1 \%)$ & $12(5.8 \%)$ & 145 & $(21.5 \%)$ & $6(4.1 \%)$ & $62(34.1 \%)$ & $6(9.7 \%)$ \\
\hline Female, n (\%) & $640(74.7 \%)$ & $35(5.5 \%)$ & 521 & $(77.2 \%)$ & $19(3.6 \%)$ & $119(65.4 \%)$ & $16(13.4 \%)$ \\
\hline Unspecified, n (\%) & $10(1.2 \%)$ & $0(0.0 \%)$ & 9 & $(1.3 \%)$ & $0(0.0 \%)$ & $1(0.5 \%)$ & $0(0.0 \%)$ \\
\hline Thai & 847 & $47(5.5 \%)$ & 671 & & $25(3.7 \%)$ & 176 & $22(12.5 \%)$ \\
\hline Non-Thai & 10 & $0(0.0 \%)$ & 4 & & $0(0.0 \%)$ & 6 & $0(0.0 \%)$ \\
\hline \multicolumn{8}{|l|}{ Region } \\
\hline North & 61 & $1(1.6 \%)$ & 59 & & $1(1.7 \%)$ & 2 & $0(0.0 \%)$ \\
\hline Northeast & 269 & $8(3.0 \%)$ & 220 & & $4(1.8 \%)$ & 49 & $4(8.2 \%)$ \\
\hline Central & 244 & $29(11.9 \%)$ & 183 & & $12(6.6 \%)$ & 61 & $17(27.9 \%)$ \\
\hline South & 109 & $2(1.8 \%)$ & 88 & & $2(2.3 \%)$ & 21 & $0(0.0 \%)$ \\
\hline East & 174 & $7(4.0 \%)$ & 125 & & $6(4.8 \%)$ & 49 & $1(2.0 \%)$ \\
\hline \multicolumn{8}{|c|}{ History of travel to high risk area } \\
\hline Yes & 51 & $2(3.9 \%)$ & 20 & & $1(5.0 \%)$ & 31 & $1(3.2 \%)$ \\
\hline No & 806 & $45(5.6 \%)$ & 655 & & $24(3.7 \%)$ & 151 & $21(13.9 \%)$ \\
\hline \multicolumn{8}{|c|}{ History of close contact confirmed case } \\
\hline Yes & 132 & $6(4.5 \%)$ & 121 & & $5(4.1 \%)$ & 11 & $1(9.1 \%)$ \\
\hline No & 725 & $41(5.7 \%)$ & 554 & & $20(3.6 \%)$ & 171 & $21(12.3 \%)$ \\
\hline Asymptomatic & 690 & $31(4.5 \%)$ & 566 & & $20(3.5 \%)$ & 124 & $11(8.9 \%)$ \\
\hline Symptomatic & 167 & $16(9.6 \%)$ & 109 & & $5(4.6 \%)$ & 58 & $11(19.0 \%)$ \\
\hline Fever & 49 & $7(14.3 \%)$ & 17 & & $0(0.0 \%)$ & 32 & $7(21.9 \%)$ \\
\hline Cough & 83 & $8(9.6 \%)$ & 52 & & $1(1.9 \%)$ & 31 & $7(22.6 \%)$ \\
\hline Rhinitis & 64 & $7(10.9 \%)$ & 47 & & $2(4.3 \%)$ & 17 & $5(29.4 \%)$ \\
\hline Sore throat & 55 & $8(14.5 \%)$ & 37 & & $3(8.1 \%)$ & 18 & $5(27.8 \%)$ \\
\hline Dyspnea & 30 & $9(30.0 \%)$ & 3 & & $1(33.3 \%)$ & 27 & $8(29.6 \%)$ \\
\hline \multicolumn{8}{|l|}{ Previous PCR status } \\
\hline Negative & 124 & $8(6.5 \%)$ & 77 & & $1(1.3 \%)$ & 47 & $7(14.9 \%)$ \\
\hline Never tested & 733 & $39(5.3 \%)$ & 598 & & $24(4.0 \%)$ & 135 & $15(11.1 \%)$ \\
\hline
\end{tabular}

Data were presented in counts and percentages unless otherwise specified.

$140 \mathrm{IgM+}$, immunoglobulin M positive; NA, not available; PCR, polymerase chain reaction.

143 COVID-19 prevalence was 2.44 cases per 100,000. Participating provinces in the Eastern region had the highest

144 prevalence of COVID-19 (6.54 cases per 100,000) while provinces in northeastern had the lowest prevalence

145 [Table 4]. There was no correlation between IgM seroprevalence and PCR confirmed COVID-19 prevalence

$146(\mathrm{p}=0.199)$. 
medRxiv preprint doi: https://doi.org/10.1101/2020.06.24.20139188; this version posted July 4, 2020. The copyright holder for this preprint (which was not certified by peer review) is the author/funder, who has granted medRxiv a license to display the preprint in perpetuity.

It is made available under a CC-BY-NC-ND 4.0 International license .

Table 4. Number and prevalence of PCR confirmed COVID-19 cases in participating provinces

\begin{tabular}{|c|c|c|c|}
\hline & $\begin{array}{l}\text { PCR Confirmed } \\
\text { COVID-19 Cases }\end{array}$ & Population & $\begin{array}{c}\text { PCR Confirmed COVID-19 } \\
\text { Prevalence per 100,000 Population }\end{array}$ \\
\hline Overall & 864 & $35,416,545$ & 2.44 \\
\hline Northern & 47 & $2,505,118$ & 1.88 \\
\hline Chiang Mai & 41 & $1,779,254$ & 2.30 \\
\hline Mae Hong Son & 5 & 284,138 & 1.76 \\
\hline Phrae & 1 & 441,726 & 0.23 \\
\hline Northeastern & 85 & $15,064,919$ & 0.56 \\
\hline Buriram & 13 & $1,595,747$ & 0.81 \\
\hline Chaiyaphum & 3 & $1,137,357$ & 0.26 \\
\hline Kalasin & 3 & 983,418 & 0.31 \\
\hline Khon Kaen & 6 & $1,802,872$ & 0.33 \\
\hline Maha Sarakham & 1 & 962,665 & 0.10 \\
\hline Mukdahan & 4 & 353,174 & 1.13 \\
\hline Nakhon Phanom & 2 & 719,136 & 0.28 \\
\hline Nakhon Ratchasima & 19 & $2,648,927$ & 0.72 \\
\hline Surin & 9 & $1,396,831$ & 0.64 \\
\hline Ubon Ratchathani & 15 & $1,878,146$ & 0.80 \\
\hline Udon Thani & 10 & $1,586,646$ & 0.63 \\
\hline Central & 383 & $10,053,397$ & 3.81 \\
\hline Ayutthaya & 4 & 820,188 & 0.49 \\
\hline Chainat & 0 & 326,611 & 0.00 \\
\hline Lopburi & 2 & 755,556 & 0.26 \\
\hline Nakhon Pathom & 22 & 920,030 & 2.39 \\
\hline Nonthaburi & 158 & $1,265,387$ & 12.49 \\
\hline Pathum Thani & 39 & $1,163,604$ & 3.35 \\
\hline Phetchaburi & 2 & 485,191 & 0.41 \\
\hline Phichit & 0 & 536,311 & 0.00 \\
\hline Samut Prakan & 143 & $1,344,875$ & 10.63 \\
\hline Sukhothai & 3 & 595,072 & 0.50 \\
\hline Suphanburi & 6 & 846,334 & 0.71 \\
\hline Tak & 3 & 665,620 & 0.45 \\
\hline Uthaithani & 1 & 328,618 & 0.30 \\
\hline Southern & 212 & $5,697,112$ & 3.72 \\
\hline Chumphon & 21 & 511,304 & 4.11 \\
\hline Krabi & 20 & 476,739 & 4.20 \\
\hline Nakhon Si Thammarat & 12 & $1,561,927$ & 0.77 \\
\hline Songkhla & 134 & $1,435,968$ & 9.33 \\
\hline Surat Thani & 18 & $1,068,010$ & 1.69 \\
\hline Trang & 7 & 643,164 & 1.09 \\
\hline Eastern & 137 & $2,095,999$ & 6.54 \\
\hline Chanthaburi & 3 & 537,698 & 0.56 \\
\hline Chonburi & 134 & $1,558,301$ & 8.60 \\
\hline
\end{tabular}

PCR, polymerase chain reaction.

IgG was detected in two participants $(0.2 \%, 95 \%$ CI $0.1-0.8)$ who also had a positive IgM antibody. In

152 other words, we did not find any participants with isolated positive IgG. Participant A was a Thai female healthcare

153 worker who worked in a community hospital in the Central region of Thailand. She had a sore throat but had no

154 history of travel to a high-risk area or close contact to confirmed COVID-19 case, and did not have a PCR test

155 before. Participant B was a Thai female preprocedural patient who visited another community hospital in the Central

156 region. She had no symptom, no history of travel to a high-risk area, or close contact to confirmed COVID-19 case.

157 Patient B had a previously negative PCR result [Table 5]. 
medRxiv preprint doi: https://doi.org/10.1101/2020.06.24.20139188; this version posted July 4, 2020. The copyright holder for this preprint (which was not certified by peer review) is the author/funder, who has granted medRxiv a license to display the preprint in perpetuity. It is made available under a CC-BY-NC-ND 4.0 International license .

Table 5. Characteristics of Participants who Developed Immunoglobulin G Antibody

\begin{tabular}{ccccccccc}
\hline & $\begin{array}{c}\text { Age } \\
\text { Range, } \\
\text { years }\end{array}$ & Gender & Ethnicity & Region & Occupation & $\begin{array}{c}\text { History of } \\
\text { travel to } \\
\text { high-risk } \\
\text { area }\end{array}$ & $\begin{array}{c}\text { History of } \\
\text { contact } \\
\text { confirmed case }\end{array}$ & $\begin{array}{c}\text { Symptoms } \\
\text { Previous } \\
\text { PCR } \\
\text { status }\end{array}$ \\
\hline Participant A & $56-60$ & Female & Thai & Central & HCW & No & No & Sore throat \\
Participant B & $41-45$ & Female & Thai & Central & Patient & No & No & Nosted \\
\hline
\end{tabular}

HCW, healthcare worker; PCR, polymerase chain reaction; Age range was used for participant's privacy and confidentiality.

161 COVID-19 seroprevalence in asymptomatic staff and patients in Thai community hospitals was higher than

162 hospitals in China (4.5\% vs. 2.5\%) [3]. Seroprevalence in asymptomatic hospital staff in Thailand was also higher

163 than hospitals in China (3.5\% vs. 1.8\%) [3] but less than a tertiary hospital in Belgium (3.5\% vs. 6.4\%) [4].

164 Asymptomatic patients in Thailand seemed to have higher seroprevalence than China (8.9\% vs. 3.5\%) [3]. Unlike

165 China and Belgium where the seroprevalences were mostly from positive IgG, our study revealed mostly positive

166 IgM. Comparison with Belgium hospital should be interpreted with caution due to the unknown PCR status of

Belgium subjects.

Serological testing provides some crucial epidemiological information and would have been more effective

when combined with other diagnostic tests such as PCR. While all participants with positive results from the free-of-

171 hospitals still did not have access to the PCR testing because of both financial and non-financial reasons.

172 Recommendation for PCR testing after positive rapid IgM/IgG test had not fully complied so we did not have

173 information about the participants with positive IgM. With immunoglobulin status and PCR results, we can shape

174 the situation more accurately for both individual and regional views. Hopefully, with this and other vigorous and

175 dedicated studies on antibody status around the globe, serology testing would provide useful information for

176 pandemic control.

\section{Conclusions}

178 COVID-19 antibody test could detect a substantial number of potential silent spreaders in Thai community hospitals.

179 Antibody testing should be encouraged for mass screening, especially in asymptomatic individuals. 
medRxiv preprint doi: https://doi.org/10.1101/2020.06.24.20139188; this version posted July 4, 2020. The copyright holder for this preprint (which was not certified by peer review) is the author/funder, who has granted medRxiv a license to display the preprint in perpetuity.

It is made available under a CC-BY-NC-ND 4.0 International license .

\section{Acknowledgements}

183 We thank Baiya Phytopharm, Thailand for supporting the Baiya Rapid COVID-19 IgG/IgM test kit. The company

184 did not involve in the data analysis, interpretation, and the manuscript preparation.

185 Author Contributions

186 Conceptualization: TN, KP, NH

187 Data curation: TN, KC, KP

188 Formal analysis: TN, KP

189 Investigation: TN, KC, KP

190 Methodology: TN, KP, NH

191 Project administration: TN, KP, NH

192 Resources: KP, NH

193 Software: TN, KP

194 Supervision: KP, NH

195 Validation: TN, KC, KP

196 Visualization: TN

197 Writing - original draft: TN, KP

198 Writing - review \& editing: TN, KP, KC, NH 
medRxiv preprint doi: https://doi.org/10.1101/2020.06.24.20139188; this version posted July 4, 2020. The copyright holder for this preprint

(which was not certified by peer review) is the author/funder, who has granted medRxiv a license to display the preprint in perpetuity.

It is made available under a CC-BY-NC-ND 4.0 International license .

\section{References}

200 1. Woloshin S, Patel N, Kesselheim A. False Negative Tests for SARS-CoV-2 Infection - Challenges and Implications. N Engl J Med. 2020. Epub 2020/06/06. doi: 10.1056/NEJMp2015897. PubMed PMID: 32502334.

202

2. Yong S, Anderson D, Wei W, Pang J, Chia W, Tan C, et al. Connecting clusters of COVID-19: an

203 epidemiological and serological investigation. Lancet Infect Dis. 2020. Epub 2020/04/25. doi: 10.1016/s1473-

204 3099(20)30273-5. PubMed PMID: 32330439; PubMed Central PMCID: PMCPMC7173813.

205

3. Xu X, Sun J, Nie S, Li H, Kong Y, Liang M, et al. Seroprevalence of immunoglobulin M and G antibodies 206 against SARS-CoV-2 in China. Nat Med. 2020. Epub 2020/06/07. doi: 10.1038/s41591-020-0949-6. PubMed

207 PMID: 32504052.

208

4. Steensels D, Oris E, Coninx L, Nuyens D, Delforge M, Vermeersch P, et al. Hospital-Wide SARS-CoV-2 Antibody Screening in 3056 Staff in a Tertiary Center in Belgium. Jama. 2020. Epub 2020/06/17. doi: 10.1001/jama.2020.11160. PubMed PMID: 32539107. 